\title{
Hubungan pemberian informasi tentang prosedur pembelian obat kepada pasien
} dengan akurasi pemberian obat

\section{Karsim $^{1}$, Ahsan $^{2}$, Tony Suharsono ${ }^{2}$}

Program Studi Magister Keperawatan Peminatan Gawat Darurat

Fakultas Kedokteran Universitas Brawijaya Malang

Korespondensi
karsimners@gmail.com $\quad \begin{aligned} & \text { The cause of the medication error from the patient is the patient's family, } \\ & \text { intake procedure. Purpose: Analyzes the relationship of information about } \\ & \text { the drug purchasing procedure to the patient with the accuracy of the drug } \\ & \text { delivery. The research design is an analytical observational study with a } \\ & \text { cross-sectional approach of } 62 \text { nurses. Sampling technique using the total } \\ & \text { sampling method. Existing data was analyzed using the Spearman rank test } \\ & \text { at a significant level of } 0.05 \text { and SPSS for Windows version 16.00. The } \\ & \text { result of the statistical test is the result of the relationship of giving } \\ & \text { information about the process of purchase of the drug to the patient with the } \\ & \text { accuracy to give the drug the correlation value of } 0.297 \text { with the significant } \\ & \text { value of } 0.016 \text { (p }<0.05) \text {. Conclusion: The provision of information on the } \\ & \text { purchase of medication for patients has a very significant correlation with } \\ & \text { the accuracy of drug delivery by the emergency department and intensive } \\ & \text { provision of information } \\ & \text { care unit at the Muhammadiyah Lamongan Hospital }\end{aligned}$

\begin{abstract}
Abstrack
Penyebab medication error dari pasien adalah keluarga pasien yang tidak kooperarif dan pemahaman keluarga pasien mengenai prosedur pengambilan obat.Tujuan : Menganalisis hubungan pemberian informasi tentang prosedur pembelian obat kepada pasien dengan akurasi tahap pemberian obat. Desain penelitian yaitu observasional analitik dengan pendekatan cross sectional yang melibatkan 62 tenaga keperawatan. Teknik pengambilan sampel menggunakan metode total sampling. Data yang ada dianalisis menggunakan Uji Spearman rank dengan taraf signifikan 0,05 dan dengan bantuan SPSS for windows versi 16.00. Hasil pengujian statistik diperoleh hasil ada hubungan pemberian informasi prosedur pembelian obat kepada pasien dengan akurasi pemberian obat dengan nilai korelasi sebesar 0,297 dengan tingkat signifikan 0,016 $(\mathrm{p}<0,05)$.Kesimpulan : pemberian informasi tentang pembelian obat kepada pasien memiliki hubungan yang sangat bermakna dengan akurasi tahap pemberian obat oleh tenaga keperawatan di unit gawat darurat dan ruang intensif Rumah Sakit Muhammadiyah Lamongan.
\end{abstract}

Keyword : pemberian obat, pemberian informasi 


\section{PENDAHULUAN}

Menurut Tajudin (2012) salah satu ukuran capaian dalam keselamatan pasien adalah angka kejadian kesalahan pemberian obat. kesalahan pemberian obat salah satu hal yang dapat memberatkan pasien karena penggunaan obat dalam perawatan, yang seharusnya dapat dicegah. Medicatin error dapat dimulai dari fase peresepan (prescribing), penyiapan obat serta fase pemberian obat. Apabila ada fase terdapat kesalahan maka akan dapat mengakibatkan secara beruntun kesalahan pada fase berikutnya. Kejadian medication error dapat meliputi dari petugas, obat, prosedur, sarana dan prasarana atau sistem yang terkait dengan peresepan, penyiapan obat dan fase pemberian obat.

Informasi yang dikeluarkan oleh the Institute of Medicine (IOM) kejadian meninggal akibat kejadian tidak diharapkan (KTD) terhadap pasien rawat inap di seluruh Amerika berkisar 44.000 98.000/ tahun, dan lebih dari 1 juta kasus harm/kerugian setiap tahun. Angka ini jauh melebihi angka kematian karena kecelakaan lalu lintas, kanker payudara ataupun AIDS (Khon et al., 2002). Lembaga kesehatan (IOM) di AS pada tahun 2000 mengeluarkan sebuah informasi yang dapat membuat terkejut banyak pihak yang berjudul "untuk kesalahan manusia" membangun kesehatan yang lebih aman. Laporan tersebut adalah hasil riset di RS di Utah, Colorado dan New york. Hasil penelitian di Utah dan Colorado menunjukkan bahwa KTD senilai 2,9\% yang didalamnya menyebabkan kematian sebesar 6,6\%. Di New York didapatkan angka KTD 3,7\% dan yang menyebabkan meninggal sebesar 13,6\%. Menurut World Health Organitation (WHO) dalam publikasikanya tahun 2004 yang menghimpun angka riset di banyak RS dan banyak negara : AS, Inggris, Denmark serta Australia menemukan antara 3,2 - 16,6\% untuk kejadian tidak diharapkan (KTD). Dengan data tersebut banyak negara melakukan riset serta pengembangan dalam sitem keselamatan pasien.

Menurut Hasil penelitian Hartati (2014) menunjukan bahwa kejadian medication error terbesar pada pasien ICU RSUD Kota Baubau berupa administration error dengan 144 kejadian (46,91\%), kemudian dispensing error dengan 119 kejadian $(38,76 \%)$, dan kejadian terkecil adalah prescribing error dengan 44 kejadian (14,33\%). Demikian pula pada pasien ICU di RS Santa Anna Kendari, angka kejadian medication error tertinggi berupa administration error, yaitu 81 kejadian $(42,6 \%)$, diikuti prescribing error, yaitu 71 kejadian $(37,4 \%)$, dan dispensing error, yaitu 38 kejadian (20\%). Faktor-faktor yang turut mempengaruhi kejadian medication error adalah persoalan sistem (minimnya kelengkapan fasilitas di rumah sakit), profesional (sumber daya manusia, meliputi dokter, tenaga farmasis, serta perawat), dan dokumentasi.

Hasil ini didukung oleh penelitian Pratiwi (2015) menyatakan cepat lambatnya pemberian obat tergantung kepada karakter individu masing- 
masing perawat. Bila keluarga pasien telah mengambil obat di apotek, obatnya tidak segera diberikan kepada petugas perawat atau dokter, tetapi obatnya disimpan saja, akibatnya terjadi kesalahan waktu pemberian obat. Hal ini juga dapat disebabkan karena sikap petugas yang tidak berinisiatif untuk menanyakan obatnya kepada keluarga pasien. Perawat atau dokter sering gagal dalam menyampaikan informasi tentang pemberian obat. Kegagalan ini menyebabkan pemberian obat yang salah dan penundaan pemberian obat serta kesalahan pemberian dosis obat. Menurut Handayani (2017) Penyebab administration error adalah faktor petugas kesehatan yaitu budaya kerja; faktor lingkungan kerja yaitu kesibukan kerja; faktor pasien yaitu keluarga pasien yang tidak kooperarif dan pemahaman keluarga pasien mengenai prosedur pengambilan obat.

Faktor penyebab insiden keselamatan pasien (IKP) menurut Cahyono (2008) adalah kegagalan komunikasi dan human error yang menyebabkan kejadian malpraktek, meningkatkan biaya operasional, biaya perawatan penyembuhan dan menghambat proses pemberian asuhan keperawatan. Hasil penelitian Anugraheni (2010) menyebutkan banyak faktor yang mempengaruhi penerapan pedoman patient safety salah satunya faktor individu yaitu usia, pendidikan, masa kerja . Di dukung oleh penelitian Fachri (2008) masa kerja dan ciri kepribadian sangat mempengaruhi seseorang untuk berubah . Sehingga faktor kepribadian dan karakteristik individu inilah yang kemungkinan berkontribusi dengan insiden keselamatan pasien dan tidak menutup kemungkinan juga mempengaruhi seseorang untuk menerapkan prinsip benar dalam pemberian obat.

Menurut laporan TIM KPRS Rumah Sakit Muhammadiyah Lamongan tahun 2017 dari bulan Januari sampai dengan bulan April dilaporkan insiden keselamatan pasien (IKP) ada 32 kejadian dengan kasus tertinggi adalah medical error. Kejadian medication error sebesar 14 kejadian atau $43,7 \%$ dari total kejadian kejadian. Salah obat adalah kejadian yang tertinggi sebesar 8 pasien atau $61 \%$ serta salah dosis sebesar 3 pasien atau $23 \%$ dari total kejadian. Melihat data yang diperoleh oleh peneliti maka peneliti berpendapat penting dapat menganalisa hubungan pemberian informasi prosedur pembelian obat terhadap akurasi pemberian obat pada penerapan keselamatan pasien. Tujuan penelitihan ini adalah untuk menganalisis hubungan pemberian informasi prosedur pemberian obat dengan akurasi pemberian obat oleh tenaga perawat di unit gawat darurat dan ruang intensif rumah sakit Muhammadiyah Lamongan.

\section{METODE}

Peneliti menggunakan desain penelitian yaitu observasional analitik dengan pendekatan cross sectional. Tempat penelitian ini dilakukan di instalasi gawat darurat dan ruang intensif Rumah Sakit Muhammadiyah Lamongan. Sampel pada penelitian ini adalah total responden pada populasi 
yaitu sebanyak 21 perawat di unit gawat darurat dan 41 perawat di ruang intesif.

Instrumen dalam penelitihan penelitihan ini terdiri dari dua jenis yaitu lembar kuesioner dan observasi. Kuesioner digunakan untuk mengumpulkan data penelitian pemberian informasi prosedur pemberin obat. Lembar observasi digunakan untuk akurasi pemberian obat. Uji validitas dan reabilitas instrumen dalam penelitian ini dilakukan di Rumah Sakit UMM dengan jumlah responden 10 perawat. Aplikasi SPSS versi 16 digunakan dalam uji validitas ini dengan teknik korelasi bivariate person (product moment pearson), tingkat kepercayaan 95\%. Signinifikansi $5 \%=0,05$. Hasil uji validasi $\mathrm{r}$ hitung kemudian dibandingkan dengan nilai $r$ table dimana $r$ hitung $>r$ table $(0,576)$ maka instrument atau item pertanyaan berkorelasi signifikan terhadap skor total dan dapat dinyatakan valid. Reabilitas indeks yang menunjukan sejauh mana kepercayaan, keandalan dan konsisten di suatu alat ukur yang digunakan dalam penelitian, dan harus dilakukan suatu uji. Pengujian ini dilakukan menggunakan aplikasi SPSS versi 16 dengan teknik alpha (cronbach's) dan menggunakan uji Kuder Richardson, instrumen yang dipakai dapat dikatakan reliable jika $\mathrm{r}$ alpha bernilai $>0,6$.

Uji analisis dalam penelitian ini adalah analisis univariat data demografi dan karakteristik responden disajikan dalam bentuk prosentase. Analisis bivariat uji korelasi menggunakan uji statistic spearman rank dengan menggunakan software aplikasi SPSS versi 16.

\section{Hasil}

Tabel 1 Distribusi Responden Berdasarkan Informasi Tentang Prosedur Pembelian Obat Kepada Pasien

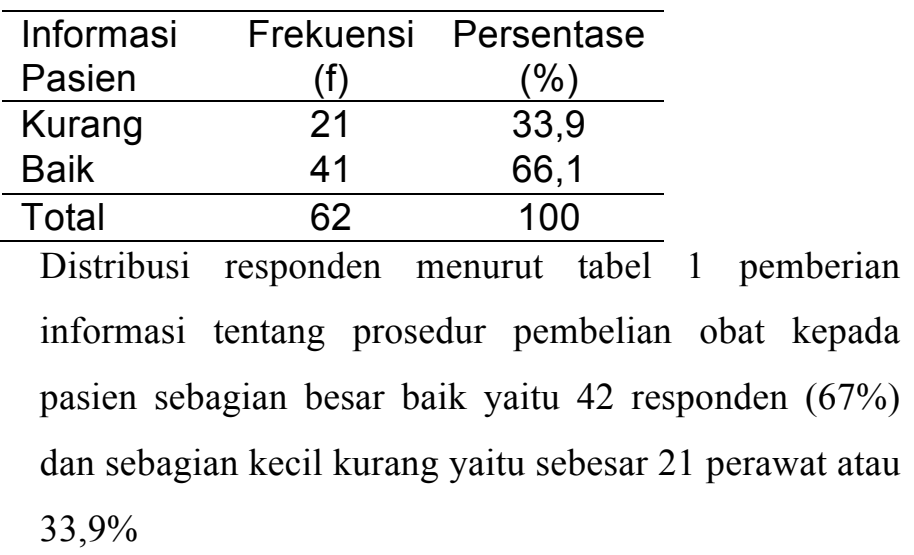

Tabel 2 Analisis hubungan linkungan kerja dengan akurasi pemberian obat

\begin{tabular}{cccc} 
& $\mathrm{n}$ & $\mathrm{r}$ & $\mathrm{p}$ \\
\hline Pemberian & 62 & 0.312 & $0.014^{*}$
\end{tabular}

informasi

$\mathrm{P}^{*}$ signifikan terhadap tahap pemberian obat

Pada Tabel 2 menunjukkan hasil di atas bahwa hubungan informasi prosedur pembelian obat dengan akurasi pemberian obat menunjukan hubungan yang kuat dan berpola positif yang artinya semakin tinggi informasi prosedur pembelian obat kepada pasien semakin baik akurasi pemberian obatnya. Nilai hubungan sebesar $\mathrm{r}=0,312$. Nilai $\mathrm{p}=0,014$ atau nilai $\mathrm{p}<\alpha$ (0.05) sehingga H0 ditolak yang berarti ada hubungan yang signifikan antara informasi prosedur pembelian obat kepada pasien dengan akurasi pemberian obat. 


\section{Pembahasan}

Hasil analisis univariat pemberian informasi prosedur pembelian obat kepada pasien sebagian besar baik. Hasil penelitian di lapangan didapatkan bahwa pemberian informasi prosedur pembelian obat kepada pasien yang masih belum baik yang berkaitan dengan penjelasan tentang prosedur pembelian obat. Hal tersebut berakibat informasi dari pasien tentang pembelian obat kepada perawat juga masih belum baik.

Hasil analisis bivariat bahwa hubungan pemberian informasi pembelian obat kepada pasien dengan akurasi pemberian obat menunjukan hubungan yang kuat dan berpola positif yang artinya semakin tinggi pemberian informasi prosedur pembelian obat kepada pasien semakin baik akurasi tahap pemberian obat. Nilai hubungan sebesar $r=0,297$. Nilai $\mathrm{p}=0,016$ atau nilai $\mathrm{p}<\alpha(0.05)$ yang berarti ada hubungan yang signifikan antara pemberian informasi prosedur pembelian obat kepada pasien dengan akurasi tahap pemberian obat.

Hasil penelitian di lapangan menunjukan bahwa masih ada $32 \%$ responden yang belum baik dalam memberikan penjelasan prosedur pembelian obat kepada pasien. Hal ini juga sesuai dengan penemuan pada kepatuhan SPO pemberian obat high alert masih ada $12 \%$ yang tidak memberikan penjelasan tentang prosedur pemberian obat. Hal ini juga didukung oleh hasil informasi obat sudah terbeli atau belum sebesar 29\%. Akibat dari belum baiknya pemberian informasi prosedur pembelian obat kepada pasien dapat mengakibatkan adanya penundaan waktu dalam pemberian obat. Hasil penelitian menunjukan bahwa akurasi tahap pemberian obat yang mengenai dengan ketepatan waktu ada 8 kali ketidaksesuaian waktu pemberian obat..

Hasil penelitian menunjukan bahwa akurasi tahap pemberian obat yang mengenai dengan ketepatan waktu ada 8 kali ketidaksesuaian waktu pemberian obat. adanya ketidaktepatan waktu pemberian obat ini dapat disebabkan oleh obat memang belum tersedia di pasien dan juga tidak adanya informasi dari keluarga pasien bahwa obat sudah terbeli sehingga obat tidak dapat dimasukan sesuai dengan jadwal yang ada. Pemberian informasi prosedur pembelian obat ketika tidak berjalan dengan baik maka akan mempengaruhi proses pemberian obat terutama berkaitan dengan waktu. Ketidaksesuaian waktu akibat obat belum terbeli maupun belum adanya informasi kalau obat sudah ada dapat juga di akibatkan kurang inisiatifnya perawat untuk menanyakan kepada kelurga maupun keluarga pasien yang kurang kooperatif.

Hasil ini didukung oleh penelitian Pratiwi (2015) menyatakan cepat lambatnya pemberian obat tergantung kepada karakter individu masingmasing perawat. Bila keluarga pasien telah mengambil obat di apotek, obatnya tidak segera diberikan kepada petugas perawat atau dokter, tetapi obatnya disimpan saja, akibatnya terjadi kesalahan waktu pemberian obat. Hal ini juga dapat disebabkan karena sikap petugas yang tidak berinisiatif untuk menanyakan obatnya kepada keluarga pasien. Perawat atau dokter sering gagal 
dalam menyampaikan informasi tentang pemberian obat. Kegagalan ini menyebabkan pemberian obat yang salah dan penundaan pemberian obat serta kesalahan pemberian dosis obat. Menurut Handayani (2017) Penyebab administration error adalah faktor petugas kesehatan yaitu budaya kerja; faktor lingkungan kerja yaitu kesibukan kerja; faktor pasien yaitu keluarga pasien yang tidak kooperarif dan pemahaman keluarga pasien mengenai prosedur pengambilan obat.

Menurut Pratiwi et al 2016 pada proses simulasi komunikasi informasi obat, hasil menunjukkan bahwa sebagian besar responden yang mengikuti proses simulasi informasi obat sudah menyampaikan atau menanyakan hal-hal penting yang perlu diketahui berhubungan dengan informasi obat. ASHP Guidelines on Preventing medication error in Hospital (2003) menyampaikan bahwa, kurangnya komunikasi antara perawat dengan pasien berpotensi menyebabkan kejadian medication error. Lebih lanjut dijelaskan bahwa, salah satu peran perawat dalam pencegahan medication error adalah perawat wajib untuk menginformasikan segala sesuatu yang berkaitan dengan diagnosa dan informasi seputar pengobatan pasien.

Menurut feleke (2015) dampak signifikan dari kesalahan pemberian obat mempengaruhi pasien dalam hal morbiditas, mortalitas, efek samping obat, dan peningkatan lama rawat di rumah sakit. Ini juga meningkatkan biaya untuk dokter dan sistem kesehatan. Oleh karena itu, menilai besarnya dan faktor terkait dari pemberian obat kesalahan memiliki kontribusi yang signifikan untuk meningkatkan kualitas perawatan pasien.

Pemberian informasi prosedur pembelian obat dengan baik akan dapat mempengaruhi akurasi pemberian obat sehingga diharapkan akan dapat mencegah terjadinya insiden keselamatan pasien.

\section{Kesimpulan}

kesimpulan dari penelitian ini adalah pemberian informasi tentang pembelian obat kepada pasien memiliki hubungan yang sangat bermakna dengan akurasi pemberian obat. peran dari perawat untuk menjelaskan prosedur pembelian obat yang baik serta peran pasien dan keluarga yang kooperatif akan dapat menghindari ketidaksesuaian waktu pemberian obat.

\section{Reference}

Anugraheni, C., (2010). Hubungan faktor individu dan organisasi dengan kepatuhan perawat dalam menerapkan pedoman patient safety di RSAB Harapan Kita Jakarta. Depok.

Cahyono, (2008). Membangun budaya keselamatan pasien dalam praktek kedokteran. Yogyakarta: Kanisius

Fachri MW, (2008). Hubungan ciri kepribadian usia, masa kerja, tingkat pendidikan, jenis kelamin dengan kesiapan untuk berubah. Jakarta.

Feleke SA, Mulatu MA, Yeswaw YS (2015) Medication administration error: magnitude and associated factors among nurses in Ethiopia Feleke et al. BMC Nursing (2015) 14:53 DOI 10.1186/s12912-015-0099-1 
Hartati, Lolok, NH, Fudholi A, Satibi. 2014. Analisis kejadian medication error pada pasien ICU. Jurnal Manajemen dan Pelayanan farmasi. Vol 4 no 2 juni 2014

Kohn L, Corrigan J, Donaldson M. 2000. To err is human : building a safer health system. Report of the committee on quality of health care in America, institute of medicine, washington. National Academy Press.

Pratiwi H, Nuryanti, Fera VV, Warsinah et al. 2016. Pengaruh Edukasi Terhadap Pengetahuan, Sikap, Dan Kemampuan Berkomunikasi Atas Informasi Obat. KARTIKA-JURNAL ILMIAH FARMASI, Jun 2016, 4(1), 10-15 p-ISSN 2354-6565 /e-ISSN 2502-3438

Pratiwi, A.H .2015. Adverse drug event's

Handayani M., Anggraeni R., Maidin M.A.,2014. Determinan Kepatuhan Perawat Di Ruang Rawat Inap Rumah Sakit Stella Maris Makassar.

Society of Health-System Pharmacists, American. (2002). ASHP guidelines on preventing medication errors in hospitals. Am J Healthsyst Pharm. 59. 1648-1668.

Tajuddin RS., Sudirman I., Maidin A., 2012. Faktor penyebab medication error di instalasi rawat darurat. Jurnal manajemen pelayanan kesehatan volume 1 